\title{
Growth Promotion of Lettuce by Biofertilizer, BIOACTIVE, Prepared from Bacillus subtilus HR-1019 and N-acetyl-thioproline
}

\author{
Yong-Suk Lee, Dong-Ju Park', Jae Hoon Kim², Hyeong Seok Kim², Soo Yeol Chung ${ }^{3}$ and \\ Yong-Lark Choi ${ }^{1}$ * \\ ${ }^{1}$ Department of Biotechnology, College of Natural Resources and Life Science, Dong-A University, Busan 604-714, Korea \\ ${ }^{2}$ Haerim Pharmetic LTD, Busan 617-736, Korea \\ ${ }^{3}$ Department of Food and Baking Science, Dong-Ju University, Busan 604715, Korea
}

Received December 13, 2012 /Revised January 15, 2013 / Accepted January 15, 2013

\begin{abstract}
A biofertilizer, BIOACTIVE, was manufactured by N-acetyl-thioproline (ATCA) and mineral phosphate solubilizing bacteria. The growth promoting effect of the biofertilizer on lettuce was evaluated under three different pot conditions, and its stability was assessed in the field. According to the results of the pot experiments, plant growth was improved compared with that of control: $128 \%, 122 \%$, and $153 \%$ for the leaf number, leaf length, and leaf mass, respectively. Applying the manufactured biofertilizer increased the concentration of phosphate: $118 \%$ and $132 \%$ in the cultivation soil and plant cells, respectively. These show that BIOACTIVE may have potential as an effective biofertilizer in agriculture.
\end{abstract}

Key words : Bacillus subtilis, growth promotion, lettuce, $\mathrm{N}$-acetyl-thioproline

\section{서 론}

아미노산이 식물에 미치는 영양에 대해서는 깊이 있는 연구 가 진행 되지는 못했지만, 아미노산을 유일한 질소원으로 하 여 식물을 키웠을 경우, 염기성 아미노산인 Glutamine, Asparagine, Arginine, Citrulline, Ornithine 등은 화학비료 상 태의 암모니아나 질산을 질소원으로 하였을 경우보다 생육이 좋아지는 아미노산의 효과가 알려져 있다. 식물생장촉진 미생물 이 생산하는 대표적인 식물호르몬인 옥신(auxin)은 Tryptopan에 서 유래된 물질로서 이 계열의 indole-3-acetic acid (IAA)는 식물생장촉진을 위한 다양한 생리적 기능을 유도한다고 잘 알려져 있다 $[5,7,8]$. 황 함유 아미노산인 Cystine과 Methionine 은 냉해, 일조부족으로 인한 생리장해 극복에 효과가 있고, Leucine은 과색의 촉진, Arginine은 병원균 생육억제, Glycine 과 Alanine은 당도 증가, Proline은 생식생장에 효과가 있는 것으로도 알려지고 있다. Cysteine 보다 더욱 안정화된 유도체 인 N-acetyl-thioproline (ATCA)를 이용한 식물생리활성 능 력의 확인은 농가의 소득 증가와 아울러 농업 발전에 기여하 는 바가 클 것으로 생각된다.

토양 중에는 식물이 이용할 수 없는 불용성 인산의 형태로

*Corresponding author

Tel : +82-51-200-7585, Fax : +82-51-200-6536

E-mail : ylchoi@dau.ac.kr

This is an Open-Access article distributed under the terms of the Creative Commons Attribution Non-Commercial License (http://creativecommons.org/licenses/by-nc/3.0) which permits unrestricted non-commercial use, distribution, and reproduction in any medium, provided the original work is properly cited
축적되는 문제를 해결하는 수단으로 불용성 인산의 가용화 능력을 가진 미생물을 이용한다[3, 10]. 이렇게 불용성 인산의 이용으로 식물의 생장을 축진 시키는 긍정적인 효과를 보여주 는 인산 가용화 균을 이용한 환경친화형 생물비료인 미생물처 리제 (biofertilizers)의 개발노력은 부단히 이루어져 왔으며, 인산의 흡수를 증대시켜 작물의 수량증가를 보여준 연구결과 도 잘 알려져 있다 $[2,6,9,11,12]$

환경보전을 위한 노력으로 화학비료의 사용 제한이 심화될 것으로 판단되기 때문에 난용성 인산염을 효율적으로 분해하 여 인산질 비료성분을 충분히 공급해줄 수 있는 토양미생물의 탐색과 biofertilizers의 개발은 시급히 해결해야 할 과제다. 그 러나 알려진 인산가용화 미생물을 이용한 미생물처리제의 개 발 에서는 장기간 안정적인 생존 상태를 유지시키기는 제품의 개발이 커다란 문제점으로 대두되기도 한다[1-3, 10, 11, 14].

따라서 본 연구는 난용성 인산염을 가용화 미생물의 적용범 위 확대를 위하여 ATCA를 첨가한 미생물처리제를 제조하였 다. 이 미생물처리제 “BIOACTIVE"의 식물생장 촉진 능력을 검증 함으로써 미생물 비료의 개발과 실용화를 위한 기초자료 를 확립하고자 실시하였다.

\section{재료 및 방법}

\section{$\mathrm{ATCA}$ 의 제조 및 분석}

L-cysteine 염산염 1수화물 $400 \mathrm{~kg}$ 을 증류수 $400 \mathrm{~kg}$ 에 녹이고, 교반 하면서 $35 \%$ 포르말린 $195 \mathrm{~kg}$ 을 서서히 투입하면서 $20^{\circ} \mathrm{C}$ 이하를 유지하면서 8시간 이상 반응을 시킨다. 반응이 완료되 면 이 반응액에 무수초산 $233 \mathrm{~kg}$ 을 천천히 투입하면서 $80^{\circ} \mathrm{C}$ 
이하에서 아세틸레이션을 시킨다. 이후 반응 액은 농축하여 생성된 ATCA를 회수하였다. HPLC 분석은 ThermoHypersil $\mathrm{BDS} C 18(250 \times 4.6 \mathrm{~mm}, 5 \mathrm{u})$ 컬럼을 $40^{\circ} \mathrm{C}$ 로 설정하여 사용하였 으며, Waters사의 UV detector (2487)를 이용해서 $220 \mathrm{~nm}$ 에서 측정하였다. 이동상으로는 acetonitrile과 $0.1 \%$ trifluoroacetic acid 를 $60: 40$ 의 비율로 혼합하여 $0.7 \mathrm{ml} / \mathrm{min}$ 으로 흘리며 분석 하였다.

\section{미생물처리제 BIOACTIVE의 제조 및 안정성 시험}

실험실 보관 균주 Bacillus sp. HR 1019 (KACC 91711P)를 전 배양하여 $10 \mathrm{ml}$ 를 21 삼각 플라스크에 멸균시켜 준비한 $700 \mathrm{ml}$ 의 LB (yeast extract $5 \mathrm{~g}, \mathrm{NaCl} 5 \mathrm{~g}$, sucrose $1 \mathrm{~g} / \mathrm{l}$ )에 접종한 후 $37^{\circ} \mathrm{C}, 180 \mathrm{rpm}$ 의 속도로 24 시간 동안 진탕 배양하였 다. 본 배양은 전 배양한 배양액을 1001 용량의 생물 배양기에 멸균시켜 준비한 701 의 동일배지에 $1 \%(\mathrm{v} / \mathrm{v})$ 를 접종하여 전 배양과 동일한 방법으로 2 일간 배양하였다. 배양액에 $700 \mathrm{~g}$ 의 탈지분유를 넣어 충분히 교반 후 원심분리하여 집균을 하였 다. 집균된 균체를 적당한 양의 멸균수에 녹이고, 동결건조 용기에 넣어 $-70^{\circ} \mathrm{C}$ 냉동고에서 overnight 시킨다. 동결된 균주 를 동결건조기에 넣어서 수분을 완전히 증발시키고, 전체 중 량 대비 인산가용화균 $0.1 \%$, ATCA $20 \%$, 첨가물로 아미노산 분말 $80 \%$ 를 혼합하여 제조한 것을 BIOACTIVE 시제품으로 하였다. 제조한 시제품의 안정성을 확인하기 위하여 가혹시험 을 실시하여 제품의 유통기한이 1 년 이상이 되는 것을 시제품 으로 재배시험에 활용하였다.

\section{미생물처리제의 처리 및 생육조사}

공시 미생물처리제 “BIOACTIVE"의 처리가 식물 생장 및 인산함량 변화의 농업환경 개선을 확인하고자 공시작물은 상 추(품종: 포마린)를 사용하고, 부산시 하단2동 소재 동아대학 교 온실에서 2012년 6월 10일부터 8월 20일까지 시험을 실시 하였다. 본 Pot 시험 처리 구는 무처리 구, 멸균 처리 구, 관행 $(\mathrm{N}, \mathrm{P}, \mathrm{K})$ 처리 구, 배 량(BIOACTIVE 500배 희석) 처리 구, 기준 량(BIOACTIVE 1000배 희석) 처리 구, 반 량(BIOACTIVE 2000 배 희석) 처리 구 등 6개 처리 구 3반복으로 54개 Pot에서 시험 을 하였다. 관행처리 $(\mathrm{N}, \mathrm{P}, \mathrm{K})$ 는 농촌진흥청의 작물별 표준 시비량에 준하여 상추의 기비로서 표준 시비량인 $10 \mathrm{a}$ 당 N: $3.5 \mathrm{~kg}, \mathrm{P}: 3.0 \mathrm{~kg}, \mathrm{~K}: 1.8 \mathrm{~kg}$ 를 $3.3 \mathrm{~m}^{2}$ 로 환산하여 시용하였다. 질소비료는 요소, 인산비료는 용과린, 칼리비료는 황산칼리
비료를 시용하였다. 상토를 조제하여 Pot에 넣어서 각 처리구 별로 상추 모종을 정식 하였다. 2 차례 관주 한 뒤에 수확하여 생육조사를 하였다.

\section{토양 및 식물체의 분석}

토양의 무기성분 분석은 채취한 토양 시료를 음건 후 마쇄 하여 $2 \mathrm{~mm}$ 체로 쳐서 시료를 조제하여 $\mathrm{pH}$ (토양대비 증류수 가1:5 w/v)는 토양 시료 $5 \mathrm{~g}$ 에 증류수 $25 \mathrm{ml}$ 을 가한 후 가끔 저어주면서 1시간 방치 후 $\mathrm{pH}$ meter로 측정하였다. EC (1:5)는 토양 시료 $5 \mathrm{~g}$ 에 증류수 $25 \mathrm{ml}$ 을 가한 후 가끔 저어주면서 1 시 간 방치 후 Conductivity electric meter로 측정하였다. 토양인 산 분석은 토양시료 $5 \mathrm{~g}$ 에 Lancaster 침출액 $20 \mathrm{ml}$ 을 가한 후 10 분간 진탕 침출하여 ammonium molybdate의 청색으로 발 색시켜 비색 측정 하였고, 토양 중 양이온 $(\mathrm{Ca}, \mathrm{Mg}, \mathrm{K})$ 분석은 치환성 이온은 토양 침출액으로 원자흡광 분석기로 측정하였 다. 식물체의 분석은 식물체에 묻어 있는 토양 및 이물질 제거 한 후 열풍건조기에서 16 시간 건조한 다음 분쇄 하였다. 그리 고 $0.5 \mathrm{~g}$ 취한 후 $10 \mathrm{ml}$ 질산을 넣고 microwave로 분해, 여과 (No. 6)한 시료를 ammonium metavanadate시약으로 발색 시 킨 후에 분광광도계로서 측정하여 인산 함량을 측정하였다[4].

\section{결과 및 고찰}

\section{$\mathrm{ATCA}$ 의 조제 및 안정성}

반응 용액에서 회수한 ATCA의 정성 및 정량 분석은 고속 액체 크로마토그래피(High-Performance Liquid Chromatography, HPLC)를 이용하여 분석 확인하였다. 생성된 ATCA를 회수한 최종 수율은 $82 \%$ 로 약간 떨어지는 경향이 있었지만, 여액 회수여부에 따라 수율의 정도는 다소의 차이가 날 수 있을 것으로 본다. 합성된 시료는 $45^{\circ} \mathrm{C}$ 의 가혹 조건에서 보관 하면서 ATCA의 순도의 변화를 관찰하였으나 0 개월, 3 개월, 6개월의 단위까지의 실험에서는 변화 없이 안정한 순도를 유 지하는 결과를 나타냈다(Table 1).

ATCA에 대한 급성경구투여 독성은 ICR 마우스를 사용하 여 한계 투여용량인 2,000 mg/kg (체중)을 1 회 경구 투여한 후 2 주간 치사 동물, 일반중독 증상, 체중변화 및 부검 소견을 관찰하였다. 시험기간 동안 모든 투여 군에서 치사 또는 일반 중독 증상이 관찰된 동물은 없었으며, 체중 변화에 있어서는 시험 물질 투여 후 시간이 경과함에 따라 증가하였다(data not

Table 1. Stability of ATCA after incubation at severe condition

\begin{tabular}{|c|c|c|c|c|c|}
\hline Treatment & Retention Time & Amount & Area $\left(\mathrm{uV}^{*} \mathrm{sec}\right)$ & Height (uV) & Assay (\%) \\
\hline Standard & 3.851 & 0.294 & 1798430 & 105237 & 100.0 \\
\hline 0 Month & 3.852 & 0.292 & 1783641 & 105619 & 99.1 \\
\hline 3 Month & 3.852 & 0.290 & 1763843 & 105619 & 98.1 \\
\hline 6 Month & 3.852 & 0.291 & 1773590 & 106367 & 98.6 \\
\hline
\end{tabular}

ATCA is incubated at $45^{\circ} \mathrm{C}$ for 0,3 , and 6 months. 
shown).

\section{미생물처리제 BIOACTIVE의 제조 및 안정성 시험}

대량 배양하여 집균하고 동결시킨 균주를 동결건조기에 넣 어서 수분을 완전히 증발시키고, 전체 중량 대비 인산가용화 균 $0.1 \%, \mathrm{~N}$-acetyl-thioproline $20 \%$, 첨가제로 아미노산 분말 $80 \%$ 를 혼합하여 입제의 형태로 제조하였다. 미생물처리제에 존재하는 생균 수는 희석 도말법을 이용하여 조사한 결과 제 품 $\mathrm{g}$ 당 $2.57 \times 10^{7}$ 의 균 수를 나타내어 미생물처리제의 제품으 로 충분한 조건을 가지고 있었다.

제제화된 미생물처리제의 안정성 시험을 위하여 $25^{\circ} \mathrm{C}, 35^{\circ} \mathrm{C}$, $45^{\circ} \mathrm{C}$ 의 온도 조건에서 각각 20 일 간격으로 180 일 동안 균 수의 변화를 확인하였다(Table 2). 그 결과 $25^{\circ} \mathrm{C}$ 와 $35^{\circ} \mathrm{C}$ 에서는 미생 물처리제의 생균 수에는 별다른 변화가 없었다. 하지만, $45^{\circ} \mathrm{C}$ 의 가혹 조건인 고온 처리에서는 140 일 차에 약간의 감소가 있었으나, 그 이후 180 일까지는 큰 변화가 없는 것으로 보아 1 년 동안까지는 생균 수가 $10^{5}$ 이상으로 충분히 유지되리라 판단되어 시제품 제제의 안정성이 좋은 것으로 생각된다.

\section{토양의 이화학적 성질변화}

공시 미생물처리제 "BIOACTIVE"를 처리 농도 별로 관주 처리한 pot에 상추 모종을 정식하고, 재배한 후 토양을 채취하 여 토양의 이화학적 조성을 분석한 결과, $\mathrm{pH}$ 는 대체적으로 작물 생육에 적당한 조건을 넘은 변화와 공시 미생물처리제 "BIOACTIVE" 처리 간에도 $\mathrm{pH}$ 의 변화가 거의 없었다.
유기물함량은 대체적으로 무처리에서 $27 \mathrm{~g} / \mathrm{kg}$ 으로 낮게 나 타났으며, 공시 미생물처리제 "BIOACTIVE" 처리간에는 일 정한 경향은 없었으나 기준량처리에서 $39 \mathrm{~g} / \mathrm{kg}$ 으로 높게 나 타났다. 치환성 양이온의 경우 처리간 일정한 경향은 없었으 나 $\mathrm{K}$ 와 $\mathrm{Ca}$ 의 경우 관행처리에서 $0.47 \mathrm{~mol} / \mathrm{kg}$ 으로 가장 높았 고, 공시 미생물처리제 "BIOACTIVE" 처리간에도 별다른 변 화가 없는 편이였다. $\mathrm{Mg}, \mathrm{EC}$ (전기전도도)는 표준 $0.3 \mathrm{dS} / \mathrm{m}$ 인 데 분석결과 관행처리에서는 $0.3 \mathrm{dS} / \mathrm{m}$ 로 나타났으며, 다른 처리에서는 대체적으로 낮게 나타났다(data not shown).

\section{공시 미생물처리제 "BIOACTIVE"의 생육효과}

공시 미생물처리제 “BIOACTIVE"를 3회 관주 처리한 후 상추의 생장효과를 조사하고자 확인한 결과는 Fig. 1과 같이 증류수를 첨가한 대조군에 비하여 뚜렷한 생장촉진 효과를 보여 주었다. 생장효과를 조사하고자 확인한 생장 요인에 따 른 조사 결과는 Table 3 과 같다. 상추의 생육특성 조사결과 대조구인 무처리에 비해 공시 미생물처리제 "BIOACTIVE" 처리에서는 통계적 유의성이 인정되었으며, 처리 간에는 뚜렷 한 차이는 나타나지 않았다.

엽 수는 무처리가 13.78 매로 가장 적었으며, 관행처리에서 17.96매 가장 많았다. 공시 미생물처리제 “BIOACTIVE" 처리 간에는 기준량처리에서 17.62 매로 가장 많았다. 엽장을 조사 한 결과 대조구인 무처리에 비해 공시 “BIOACTIVE"를 처리 한 시험 구에서 유의성이 인정되었으며, "BIOACTIVE" 처리 간에는 뚜렷한 차이는 없었으나 배량 처리에 비해 반량 처리

Table 2. Number of viable bacterial cell after incubation at severe condition

\begin{tabular}{ccccccccccc}
\hline Temp $\left({ }^{\circ} \mathrm{C}\right)$ & 0 day & 20 day & 40 day & 60 day & 80 day & 100 day & 120 day & 140 day & 160 day & 180 day \\
\hline 25 & $3.1810^{7}$ & $2.81 \times 10^{7}$ & $2.51 \times 10^{7}$ & $2.72 \times 10^{7}$ & $2.48 \times 10^{7}$ & $2.35 \times 10^{7}$ & $2.23 \times 10^{7}$ & $1.56 \times 10^{7}$ & $0.87 \times 10^{7}$ & $0.13 \times 10^{7}$ \\
35 & $2.08 \times 10^{7}$ & $2.00 \times 10^{7}$ & $2.10 \times 10^{7}$ & $1.90 \times 10^{7}$ & $1.88 \times 10^{7}$ & $1.64 \times 10^{7}$ & $1.50 \times 10^{7}$ & $1.01 \times 10^{7}$ & $0.67 \times 10^{7}$ & $0.10 \times 10^{7}$ \\
45 & $2.58 \times 10^{7}$ & $2.24 \times 10^{7}$ & $2.24 \times 10^{7}$ & $1.84 \times 10^{7}$ & $1.52 \times 10^{7}$ & $1.09 \times 10^{7}$ & $0.88 \times 10^{7}$ & $8.9 \times 10^{6}$ & $7.30 \times 10^{6}$ & $7.89 \times 10^{6}$ \\
\hline
\end{tabular}

Biofertilizer is incubated at $25^{\circ} \mathrm{C}, 35^{\circ} \mathrm{C}$ and $45^{\circ} \mathrm{C}$ for 0 days to 6 months per 20 days
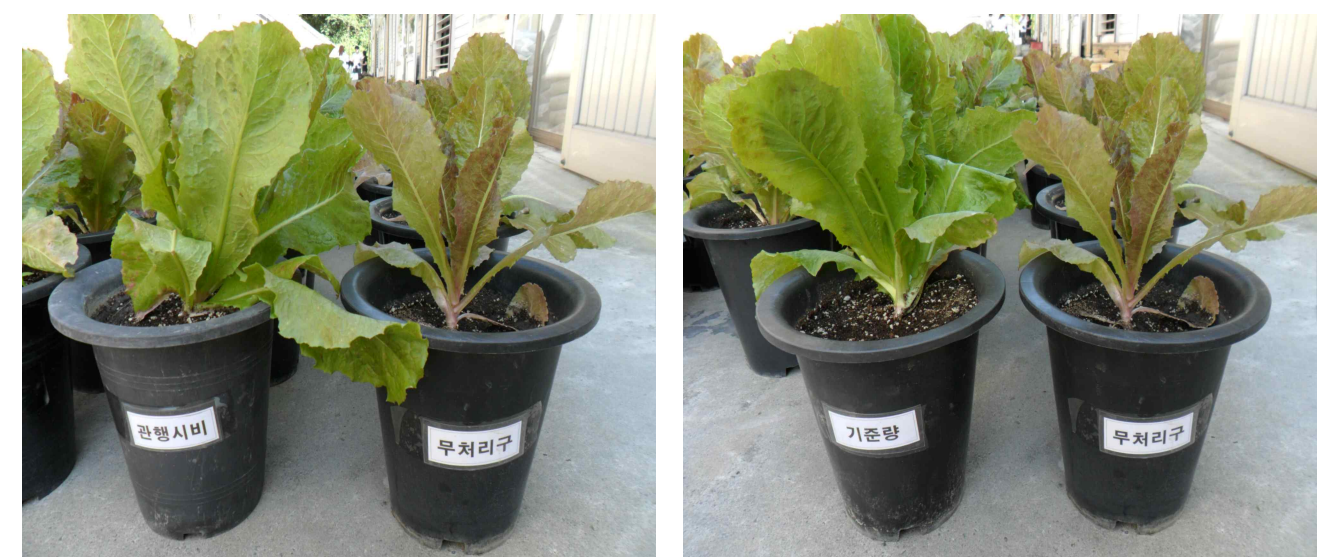

Fig. 1. Effect of biofertilizer on lettuce growth. A: General fertilization, B and D: Control, C: Fertilization of BIOACTIVE 
Table 3. Effect of biofertilizer on the growth promotion of lettuce

\begin{tabular}{|c|c|c|c|c|}
\hline & Leaf number & Leaf length $(\mathrm{cm})$ & Leaf width $(\mathrm{cm})$ & Leaf weight $(\mathrm{g})$ \\
\hline Control & $13.78 \mathrm{~d}^{1)}$ & $20.67 \mathrm{c}$ & $9.02 \mathrm{~b}$ & $58.21 \mathrm{c}$ \\
\hline Autoclaving & $14.35 \mathrm{~cd}$ & $22.17 \mathrm{c}$ & $10.14 \mathrm{ab}$ & $67.40 \mathrm{~b}$ \\
\hline Standard treatment & 17.96 a & 25.91 a & $11.18 \mathrm{a}$ & 90.12 a \\
\hline $1 / 2 \times$ Treatment & $16.38 \mathrm{ab}$ & $24.81 \mathrm{ab}$ & $11.02 \mathrm{a}$ & 87.02 a \\
\hline $1 \times$ Treatment & $17.62 \mathrm{a}$ & $25.21 \mathrm{ab}$ & $11.16 \mathrm{a}$ & 89.11 a \\
\hline $2 \times$ Treatment & $15.71 \mathrm{bc}$ & $23.94 \mathrm{~b}$ & $10.89 \mathrm{a}$ & $70.33 \mathrm{~b}$ \\
\hline L.S.D $5 \%$ & 1.07 & 1.02 & 0.82 & 3.30 \\
\hline $1 \%$ & 1.52 & 1.42 & 1.16 & 4.70 \\
\hline
\end{tabular}

${ }^{11}$ In a column, means followed by a common letter are not significantly different at the $1 \%$ level by DMRT.

및 기준량 처리에서 엽장이 다소 길었다. 처리 간에는 대조구 인 무처리에서 $20.67 \mathrm{~cm}$ 로 가장 짧았으며, 기준량 처리에서 $25.21 \mathrm{~cm}$ 로 가장 길었다. 엽폭은 대조구인 무처리에 비해 공시 미생물처리제 "BIOACTIVE" 처리에서는 통계적 유의성이 인 정되었으며, 미생물처리제 간에는 유의성은 인정되지 않았으 나 대체적으로 기준량처리에서 엽폭이 증가하였다. 엽중은 무 처리에서 $58.21 \mathrm{~g}$ 으로 공시 미생물처리제 "BIOACTIVE" 처리 에 비해 유의성이 인정되었으며, 미생물처리제 간에는 기준량 처리 및 반량 처리에서 각각 $89.11 \mathrm{~g}$ 및 $87.02 \mathrm{~g}$ 로 지상부 엽 무게가 가장 무거웠다.

이러한 결과로 볼 때 대조구인 무처리에 비해서 공시 "BIOACTIVE" 를 처리한 시험 구에서 상추의 생육이 양호하 였으며, 처리 간의 생육효과는 기준량 처리 > 반량 처리 > 배 량 처리 순으로 나타났다. 그러나, 본 연구는 소규모 토양의 pot를 이용한 단기간의 재배실험 결과이므로 실제의 농경지 환경이나 수확기까지의 전체 재배기간을 실험한 결과에는 다소간의 차이가 있을 수가 있다. 또한 토양내의 다른 미생 물과의 공생이나, 생존 여부, 작물의 차이에 따라서도 결과의 영향이 있는지는 농경지의 현장 실험이 앞으로 진행되어야 할 것이다.

\section{공시 "BIOACTIVE"에 의한 토양 및 식물의 인산함량 변화}

공시 미생물처리제 “BIOACTIVE"를 3회 관주 처리한 후 공시작물 "상추"를 재배한 재배 토양 및 상추 체내의 인(P) 함량을 분석하였다. 토양 중에서의 유효 인산 $\left(\mathrm{P}_{2} \mathrm{O}_{5}\right)$ 은 대조구 인 무처리구가 $79 \mathrm{mg} / \mathrm{kg}$ 로 가장 낮게 나타났으며, 관행처리 에서 $113 \mathrm{mg} / \mathrm{kg}$ 으로 가장 높았다. 공시 미생물처리제 "BIOACTIVE" 처리간에는 반량 처리에서 $104 \mathrm{mg} / \mathrm{kg}$ 로 다소 높았고, 기준량처리에서 $97 \mathrm{mg} / \mathrm{kg}$ 으로 다소 낮게 나타났다. 상추 체내 인 $(\mathrm{P})$ 함량을 분석한 결과는 Fig. 2와 같다.

상추 체내 인 $(\mathrm{P})$ 함량을 분석 결과 무처리 구에서는 $0.45 \%$ 로 나타났으며, 멸균처리에서는 $0.48 \%, \mathrm{~N}, \mathrm{P}, \mathrm{K}$ 를 표준시비한 관행 처리구에서는 $0.53 \%$ 로 가장 많았다. 공시 미생물처리제

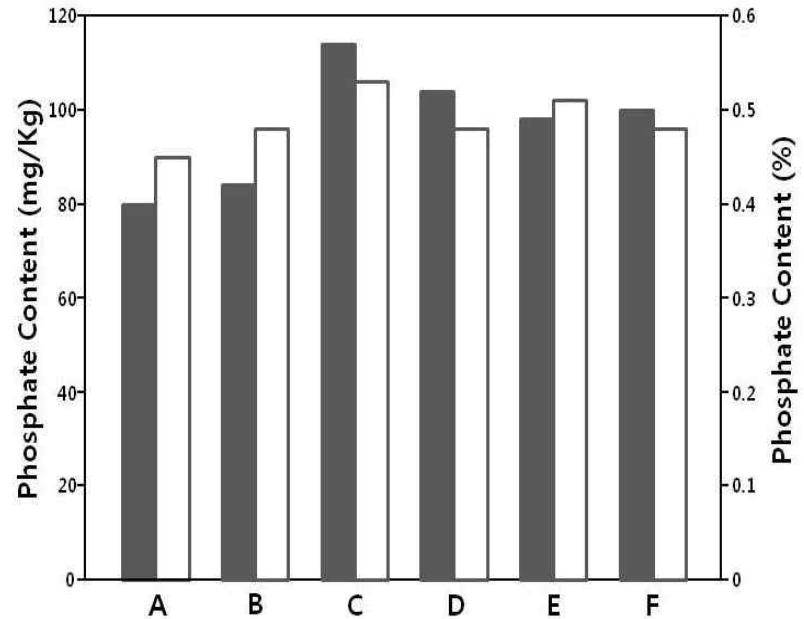

Fig. 2. Effect of phosphate concentration in soil and plant by the treatment of biofertilizer. The experiment was carried out in triplicate and the mean values with standard deviation were presented. A: Control, B: Autoclaving, C: General fertilization, D: Half amount of biofertilizer, E: Basic amount of biofertilizer, F: Double amount of biofertilizer, White stick: Phosphate concentration of soil sample, Black stick: Phosphate concentration of plant sample

“BIOACTIVE" 처리간에는 기준량처리에서 $0.51 \%$ 로 가장 많 았으며, 그 다음이 반량 처리 구에서 $0.48 \%$, 배량 처리 구에서 $0.45 \%$ 로 나타났다(Fig. 2).

이러한 결과로 볼 때 공시 미생물처리제 "BIOACTIVE"를 3 회 관주 처리한 결과 큰 차이는 없었으나 상추 체내 흡수율은 기준량 처리 > 반량 처리 > 배량 처리 순으로 흡수율이 높은 것으로 나타났다.

공시 미생물처리제 “BIOACTIVE"를 1차, 2차 및 3차 관주 처리한 후 생육조사를 실시한 결과 상추는 모든 처리 구에서 양호한 생육작황을 나타내어 "BIOACTIVE"의 관주 처리에 의한 상추의 비해 및 생육장해가 없는 것으로 확인되었다(Fig. 1). 이러한 결과는 Acidithiobacillus sp. 미생물이 rock phos- 
phate 첨가 토양 내에서 인산가용화의 효과를 나타내어 생산 된 콩의 건조 중량이 약 $8.7 \%$ 증가 되었다는 Stamford 등의 연구결과와 비슷한 경향으로 생육촉진 효과를 가져다 준 것으 로 생각되었다[13].

\section{감사의 글}

본 연구는 동아대학교의 연구비 일부로 수행되었으므로 이 에 감사드립니다.

\section{References}

1. Agasimani, C., Mudlagiriyappa, A. and Sreenivasa, M. N. 1994. Response of groundnut to phosphate solubilizing microorganisms. Groundnut News 6, 5-7.

2. Dubey, S. K. and Billore, S. D. 1992. Phophate solubilizing microorganism (PSM) as inoculant their role in augmenting crop productivity India-A review. Crop Res Hisar 5, 11-19.

3. Illmer, P. and Schinner, F. 1992. Solubilization of inorganic phosphates by microorganisms isolated from forest soils. Soil Biol Biochem 24, 389-395

4. Leach, A. M., Burden, D. L. and Hieftje, G. M. 1999. Radioilluminescense detecter for the flow injection determination of phosphorus as vanadomolydophosphoric acid. Anal Chem Acta 402, 267-274.

5. Lee, E. S. and Song, H. G. 2010. Plant growth promotion by purple nonsulfur Rhodopseudomonas faecalis strains. Korean J Microbiol 46, 157-161.

6. Lee, K. H. and Song, H. G. 2007. Growth promotion of toma- to seedlings by aplication of Bacillus sp. isolated from rhizosphere. Korean J Microbiol 43, 279-284.

7. Leveau, J. H. J. and Lindow, S. E. 2005. Utilization of plant hormone indole-3-acetic acid for growth by Pseudomonas putida strain 1290. Appl Environ Microbiol 71, 2365-2371.

8. Pattern, C. L. and Glick, B. R. 2002. Role of Pseudomonas putida indole-3-acetic acid in development of the host plant root system. Appl Environ Microbiol 68, 3795-3801.

9. Kang, S. C. and Choi, M. C. 1999. Solid culture of phosphate - solubilizing fungus, Penicillium sp. PS-113. Korean J Appl Microbiol Biotechnol 27, 1-7.

10. Son, H. J., Park, G. T., Cha, M. S. and Her, M. S. 2006. Solubilization of insoluble inorganic phosphate by a novel salt- and pH-tolerant Pantoea agglomerans R-42 isolated from soybean rhizosphere. Biores Technol 97, 204-210.

11. Song, O. R., Lee, S. J., Kim. S. H.., Chung, S. Y., Cha, I. H. and Choi, Y. L. 2001. Isolation and cultural characteristics phosphate solubilization bacterium, Aeromonas hydrophyla DA57. J Korean Soc Agric Chem Biotechnol 44, 257-261.

12. Song, O. R., Lee, S. J., Lee, Y. S., Lee, S. C., Kim, K. K. and Choi, Y. L. 2008. Solubilization of insolubile inorganic phosphate by Burkholderia cepacia DA23 isolated from cultivated soil. Bra J Microbiol 39, 1-6.

13. Stamford, N. P., Santo, P. R., Snatos, C. E. S., Freitas, A. D. S., Dias, S. H. L. and Lira, Jr. M. A. 2007. Argonomic effectiveness of biofertilizers with phosphate rock, sulfur and Acdithiobacillus for yam bean grown on a Brazilian tableland acidic soil. Biores Technol 98, 1311-1318.

14. Tiwari, V. N., Pathak, A. N. and Lehri, L. K. 1993. Rock phosphate-superphosphate in wheat in relation to inoculation with phosphate solubilizing organism and organic waste. Ind J Agr Res 27, 137-145.

\section{초록 : Bacillus subtilus HR-1019와 N-Acetyl-thioproline으로 제조한 미생물처리제, BIOACTIVE에 의 한 상추의 생장 촉진}

이용석 ${ }^{1} \cdot$ 박동주 $^{1} \cdot$ 김재훈 ${ }^{2} \cdot$ 김형석 $^{2} \cdot$ 정수열 $^{3} \cdot{\text { 최용락 }{ }^{1} \star}^{*}$

( ${ }^{1}$ 동아대학교 생명공학과, ${ }^{2}$ (주)해립파메틱, ${ }^{3}$ 동주대학교 식품제과제빵학과)

L-Cysteine에서 유도된 아미노산인 ATCA와 불용성 인산 가용화능을 가진 균주를 이용하여 미생물처리제 BIOACTIVE를 제조하고 안정성을 확인 하였다. 제조한 미생물처리제를 미생물 비료로 적용하고자 3회 관주 처 리한 다음 상추모종의 생장촉진 효과를 조사하는 실험을 수행하였다. 그 결과로 처리한 시험 구에서 상추의 생 육은 엽수, 엽장 및 엽중에서 최대 $128 \%, 122 \%$ 및 $153 \%$ 정도로 증가하였다. 처리 간에는 기준량(1,000배 희석) 처리> 반 량(500배 희석) 처리> 배 량(2,000배 희석) 처리 순으로 나타났다. 공시 BIOACTIVE의 처리가 토양 중 의 유효인산 및 식물체내의 인산함량을 최대 $118 \%$ 및 $132 \%$ 정도 증가 시키는 경향이었다. BIOACTIVE제제를 처리했을 때 $\mathrm{N}, \mathrm{P}, \mathrm{K}$ 3요소를 관행으로 처리와 비슷한 생육 효과가 있는 것으로 보아 복합비료의 사용량을 줄 여, 재배가 충분히 가능하리라 생각되며, 상추의 생육 및 비해 조사를 한 결과 본 관주 처리에서는 생육장해 및 비해는 없었다. 